\title{
Effect of increasing pasture allowance and concentrate supplementation on animal performance and microbial protein synthesis in dairy cows ${ }^{\#}$
}

\author{
Efecto del aumento en la oferta de pradera y suplementación con concentrado sobre la respuesta \\ productiva y síntesis de proteína microbiana en vacas lecheras
}

\author{
J Schöbitz ${ }^{\mathrm{a}}$, M Ruiz-Albarrán ${ }^{\mathrm{b}}$, OA Balocchía ${ }^{\mathrm{a}}$ Wittwerc, M Noroc ${ }^{\mathrm{c}}$ RG Pulido ${ }^{\mathrm{d}}$ \\ anstituto de Producción Animal, Facultad de Ciencias Agrarias, Universidad Austral de Chile, Valdivia, Chile. \\ bEscuela de Graduados, Facultad de Ciencias Veterinarias, Universidad Austral de Chile, Valdivia, Chile. \\ 'Instituto de Ciencias Clínicas, Facultad de Ciencias Veterinarias, Universidad Austral de Chile, Valdivia, Chile. \\ 'Instituto de Ciencia Animal, Facultad de Ciencias Veterinarias, Universidad Austral de Chile, Valdivia, Chile.
}

\begin{abstract}
SUMMARY
This study was undertaken to evaluate the influence of daily pasture allowance and concentrate supplementation on dairy cows during autumn. The study lasted 56 days using 30 Holstein Friesian cows. The treatments resulted from a combination of two pasture allowances $(\mathrm{L}=1$ low allowance, 20 and $\mathrm{H}=$ high allowance, $30 \mathrm{~kg}$ of DM cow ${ }^{-1} \mathrm{day}^{-1}$, measured at ground level) and three concentrate levels $\left(0,3 \mathrm{or}^{6} \mathrm{~kg} \mathrm{cow}^{-1}\right.$ day $\left.^{-1}\right)$. All the cows received $4.5 \mathrm{~kg} \mathrm{cow}^{-1} \mathrm{day}^{-1}$ of grass silage. The increase in pasture allowance had no effect on milk production $(\mathrm{P}>0.05)$, but increased the protein concentration in milk (from $3.02 \%$ to $3.21 \%$ ) $(\mathrm{P}<0.05)$, body weight gain $\left(0.336\right.$ to $-0.121 \mathrm{~kg}$ ) and the grazing time $\left(299 \mathrm{~min} \mathrm{cow}^{-1} \mathrm{day}^{-1}\right.$ to $\left.411 \mathrm{~min}^{\mathrm{cow}} \mathrm{coy}^{-1}\right)$ $(\mathrm{P}<0.001)$. Concentrate supplementation increased milk production $\left(15.1,19.2\right.$ and $21.7 \mathrm{~kg} \mathrm{cow}^{-1}$ day $\left.^{-1}\right)(\mathrm{P}<0,001)$, fat yield $\left(+0.1 \mathrm{~kg} \mathrm{cow}^{-1} \mathrm{day}^{-1}\right)$ and protein yield $\left(+0.1 \mathrm{~kg} \mathrm{cow}^{-1} \mathrm{day}^{-1}\right)$, decreasing milk urea $\left(-0.25 \mathrm{mmol} / \mathrm{L}^{-1}\right.$ day $\left.{ }^{-1}\right),(\mathrm{P}<0.001)$. Increasing pasture allowance or the concentrate offered had effect on NEFA and plasma urea-N concentration during the experiment. High pasture allowance increased $(\mathrm{P}<0.05)$ purine derivatives excretion and $\mathrm{PDPD} / \mathrm{CT}$ ratio, but not effect was observed by concentrate supplementation. Supplementation with concentrate had a positive impact on performance as a result of a better protein-energy balance of the diet.
\end{abstract}

Key words: grazing, low-mass pasture, supplementation.

\section{RESUMEN}

El objetivo de este estudio fue evaluar la influencia de la oferta diaria de pradera y la suplementación con concentrado en vacas lecheras durante el otoño. El estudio tuvo una duración de 56 días, usando 30 vacas lecheras Frisón Negro. Los tratamientos empleados fueron el resultado de la combinación de dos ofertas de pradera $\left(\mathrm{B}=\right.$ baja oferta, $20 \mathrm{~kg} \mathrm{y} \mathrm{A}=$ alta oferta, $30 \mathrm{~kg}$ de materia seca vaca $\left.\mathrm{dia}^{-1}\right)$ y tres cantidades de concentrado $(0$, 3 y $6 \mathrm{~kg} \mathrm{MS} / \mathrm{vaca} /$ día). Todas las vacas fueron suplementadas con $4,5 \mathrm{~kg}$ de MS de ensilaje de pradera vaca ${ }^{-1} \mathrm{dia}^{-1}$. La oferta de pradera no tuvo efecto sobre la producción de leche $(\mathrm{P}>0,05)$, pero sí incrementó la concentración de proteína (de 3,02\% a $3.21 \%)(\mathrm{P}<0.05)$, el peso vivo $(0,336$ a $-0,121$ $\mathrm{kg}$ ) y tiempo de pastoreo (de $299 \mathrm{~min} \mathrm{vaca}^{-1}$ dia $^{-1}$ a 411 min vaca $^{-1}$ dia $^{-1}, \mathrm{P}<0,001$ ). La suplementación con concentrado incrementó la producción de leche $\left(15,1,19,2\right.$ y $21,7 \mathrm{~kg} \mathrm{vaca}^{-1}$ día $\left.^{-1}\right)(\mathrm{P}<0,05)$, grasa $\left(+0,1 \mathrm{~kg} \mathrm{cow}^{-1}\right.$ day $\left.^{-1}\right)$ y proteína $\left(+0,1 \mathrm{~kg} \mathrm{vaca}^{-1}\right.$ día $\left.^{-1}\right)$, disminuyendo la concentración de urea láctea $\left(-0,25 \mathrm{mmol} / \mathrm{L}^{-1} \mathrm{day}^{-1}\right),(\mathrm{P}<0,001)$. Durante el experimento, la oferta de pradera o el concentrado suplementado tuvo un efecto significativo sobre las concentraciones de AGNES y urea plasmática. La mayor oferta de pradera incrementó $(\mathrm{P}<0,05)$ la excreción de derivados de purinas y el índice PD/ CT, sin observarse un efecto sobre la suplementación con concentrado. La suplementación con concentrado tuvo un efecto positivo sobre el desempeño animal, como resultado de un mejor balance proteína-energía de la dieta.

Palabras clave: pastoreo, praderas de baja disponibilidad, suplementación.

\section{INTRODUCTION}

In temperate regions, milk production is often based on perennial pastures as pasture based milk production systems are more cost effective than an indoor concentrate-based system. However, by providing pasture as the only source of nutrients it is not possible to meet the

Accepted: 04.07.2013.

\# Proyecto financiado por FONDECYT N ${ }^{\circ} 1070391$

* Casilla 567, Valdivia, Chile; rpulido@uach.cl energy requirements of high producing cows (Kolver and Muller 1998). The factors limiting milk production under pasture based systems are low herbage dry mater intake (DMI), low energy intake, and lack of synchrony in the release of nutrients in the rumen (Peyraud and Delaby 2001, Stockdale 2000). Supplementation is therefore needed in order to improve production.

In temperate regions such as south areas of South America or Australia, dairy cattle are exposed to large seasonal variations in herbage growth and nutritional quality, thereby exposing them to variable herbage 
allowance (Chilibroste et al 2007). In autumn, weather conditions usually decrease pasture growth rate to 30 $50 \mathrm{~kg} \mathrm{DM} \mathrm{ha}^{-1}$ day $^{-1}$ (Poff et al 2011); conditioning grazing dairy cows on short sward (low-mass pastures). On low-mass pasture, cows are forced to graze on low strata, strongly increasing the difficulty of biting the pasture. Under tough grazing conditions, nutrient intake from grazed pasture alone is generally insufficient to meet the requirements of dairy cows (Perez-Prieto et al 2011).

Temperate pasture in southern Chile usually has high variations in nutrient value over the different grazing seasons such as CP, dry matter (DM) and fiber concentrations (Ruiz-Albarrán et al 2012, Sotelo et al 2012, Noro et al 2013). In this production system, autumn pasture is generally in a vegetative state, dominated by $L$. perenne, (Poff et al 2011) characterized by high levels of CP (close to $30 \% \mathrm{DM})$ and a low DM content $(<17 \%)$. Excessive $\mathrm{CP}$ concentrations in the diet can have negative impact on animal production because there are significant metabolic costs for disposal of excess $\mathrm{N}$, and also because the energy yields from the oxidation of $\mathrm{CP}$ to produce high energy phosphate bonds is less than the yield from volatile fatty acid oxidation (Waghorn et al 2007).

There are two alternative management systems for grazing dairy cows that improve the supply of nutrients and rumen synchrony between energy and protein provided by the diet. The first is stimuli/motivation of pasture intake through the daily pasture allowance (Peyraud et al 1996, Kennedy et al 2008), and the second is by supplementation with conserved forages and concentrates (Phillips and Leaver 1985). Supplementary feeding of concentrate and other forages is essential for grazing dairy farming based on high forage feeding diets; however, few published studies have determined the effect of forage supplementation on the feed intake and milk production of grazing dairy cows on low mass pasture (Perez-Prieto et al 2011). Supplementary forages can be used to increase total DM intake when offered for a short period each day as a buffer feed to grazing dairy cows. Supplementing animals with concentrate has been shown to increase total DMI, and therefore total energy intake (Horan et al 2005). Supplementation with cereal-based concentrates, high in starch, are able to modify molar proportions of volatile fatty acid enhancing propionate concentration, which is the most relevant precursor of glucose in a ruminant, and therefore positively influences the energy metabolism status in the cow (Bargo et al 2003). In ruminants, the energy from carbohydrate digestion in the rumen conducts microbial protein synthesis and thus, contributes towards the protein requirements of the animal (Gozho and Mutsvangwa 2008). An increase of the ruminally available energy content of the diets for dairy cows through supplementary concentrate can potentially enhance milk production by increasing microbial protein synthesis in the rumen, because the energy supply is usually the first limiting factor for microbial growth in the rumen (Dewhurst et al 2000).
The measurement of purine derivatives (PD) as specific markers for rumen microbial biomass has been suggested (Topps and Elliot 1965). Among the purine derivatives, allantoin (A) is the most important in cattle (Chen et al 1992) and it is excreted in constant proportion to other purine derivatives. It can be used to estimate rumen microbial protein (Tas and Susenbeth 2007). Production efficiency of lactating dairy cows is optimal when the synthesis of microbial protein in the rumen is maximized (Bargo et al 2003). Little research has been conducted to evaluate the effect of diet on rumen microbial synthesis in high producing grazing dairy cows (Bargo et al 2002, Delahoy et al 2003). No previous research has evaluated the effect of concentrate level and daily herbage allowance on milk production and microbial protein efficiencies of dairy cows grazing on low mass pasture.

This study was undertaken to evaluate the influence of daily pasture allowance and the concentrate supplementation level on milk production performance, DM intake, grazing behaviour and blood, and urinary metabolites of dairy cows grazing on low mass pasture.

\section{MATERIAL AND METHODS}

\section{EXPERIMENTAL SITE}

The experiment was conducted at the Vista Alegre Experimental Research Station of the Universidad Austral de Chile, Chile (latitude $39^{\circ} 47^{\prime} 46^{\prime \prime}$ and longitude $\left.73^{\circ} 13^{\prime} 13^{\prime \prime}\right)$ from April $21^{\text {st }}$ to June $15^{\text {th }}, 2009$. The sward was a 14 yr-old permanent pasture that had been subjected to rotational grazing management in previous years. The soil type has been classified as a medial, mesic, type Hapludand (Soil Survey Staff 1992).

\section{ANIMALS}

Eighteen Friesian dairy cows (milk yield, $23.0 \pm 2.8$ $\mathrm{kg} \mathrm{d}^{-1}$; days in milk (DIM), $26 \pm 12.1$; body weight (BW), $531 \pm 50.9$; BS, $3.0 \pm$ ) and twelve Friesian dairy cows $\left(15.4 \pm 3.83 \mathrm{~kg} \mathrm{~d}^{-1}\right.$; BW, $504 \pm 64.0 \mathrm{~kg}$; BS $3.00 \pm 0.17$, DIM $196 \pm 44.8)$ were used. Cows were blocked according to milk yield, DIM, and BW and were randomly assigned within each dietary treatment.

\section{GRAZING AND FEEDING MANAGEMENT}

Grazing took place on a 13.1 ha ryegrass dominant pasture, with each treatment grazing on the same paddock, but separated by an electric fence according to their pasture allowance. All animals were given access to new pasture after each milking.

The treatments resulted from a combination of two pasture allowances $(\mathrm{L}=$ low 20 and $\mathrm{H}=$ high $30 \mathrm{~kg}$ of $\mathrm{DM}$ cow $^{-1} \mathrm{day}^{-1}$, measured at ground level) and three concentrate levels $\left(0,3\right.$ and $6 \mathrm{~kg} \mathrm{cow}^{-1}$ day $\left.^{-1}\right)$. All the cows 
received $4.2 \mathrm{~kg}$ of DM $\operatorname{cow}^{-1}$ day $^{-1}$ of grass silage, offered individually to each animal twice a day.

The concentrate had $86 \%$ corn, $9 \%$ soybean meal, and $5 \%$ beet molasses (DM basis) and was offered at $06.00 \mathrm{~h}$ and $16.00 \mathrm{~h}$, during each milking time. A mineral mix (Anasal Alta Production ${ }^{\circledR}$ : Ca 14\%, P 10\%, Mg 6\%, Na 4\%, S $0.2 \%$, Zn $5000 \mathrm{mg} \mathrm{kg}^{-1}$, Cu $1500 \mathrm{mg} \mathrm{kg}^{-1}$, Co $20 \mathrm{mg} \mathrm{kg}^{-1}$ I $200 \mathrm{mg} \mathrm{kg}^{-1}$ ) was offered with the concentrate at a rate of $0.25 \mathrm{~kg} \mathrm{cow}^{-1} \mathrm{day}^{-1}$. The amounts of conserved forage and concentrate supplement offered were calculated from the ME requirements for producing $24 \mathrm{~kg}$ milk day ${ }^{-1}$ (NRC 2001) and the anticipated contribution of the pasture.

\section{EXPERIMENTAL PROCEDURES AND SAMPLING}

Herbage mass $\left(\mathrm{kg} \mathrm{DM} \mathrm{ha}^{-1}\right)$ was measured once weekly with shearing scissors by cutting five quadrants $(0.5$ $\mathrm{m}^{2}$ ) at ground level and drying them for $48 \mathrm{~h}$ at $60{ }^{\circ} \mathrm{C}$, the grazing areas were calculated daily on a herbage mass basis, estimated from 100 measurements made with rising plate meter (RPM. Ash grove Plate Meter, Meter Hamilton, New Zealand), using the following equation $\mathrm{Y}=120 \mathrm{x}+350$, where $\mathrm{Y}$ is the herbage mass, 120 is the slope, $x$ is the height of the pasture and 350 is the intercept. Measurements were made by walking along the paddocks in a "W" pattern and this was repeated post grazing, enabling grass disappearance of each individual herd to be calculated.

Samples of concentrate, silage and pasture were collected 3 times a week during the study, pooled by week, and dried for $48 \mathrm{~h}$ at $60{ }^{\circ} \mathrm{C}$ for future analysis. Once a week, samples of the pasture consumed were obtained by hand-plucking at the approximate height to which the cows grazed. Pasture and silage samples were frozen and freeze-dried for chemical analysis. Concentrate, silage and pasture were grounded through a $1 \mathrm{~mm}$ screen (Willey Mill, 158 Arthur H, Thomas, Philadelphia, PA), and analysed for DM, crude protein (CP), Acid detergent fiber (ADF) and ash according to AOAC (1996) and the neutral detergent fiber (NDF) was determined according to Van Soest et al (1991). Metabolizable energy (ME) of pasture was estimated by regression using a " $D$ " value (digestible organic matter/ DM x 100) determined in vitro (Tilley and Terry 1963), according to Goering and Van Soest (1970).

Cows were milked at 06:00 and 15:00 h and milk yield was measured at each milking time during the nine weeks of the trial; an average of each week was used for the statistical analyses. Each week representative subsamples were collected for two consecutive days at a.m. and p.m. milking for milk fat, milk total protein and milk urea nitrogen (MUN) analyses by infrared spectrophotometer (Foss 4300 Milkoscan $^{\mathrm{TM}}$; Foss Electric, Denmark). Once a week the cows were weighed after morning milking and body condition score (BCS) was recorded by two experienced observers using the five-point scale (Ferguson et al 1994).
Individual grazing behaviour was recorded over a 24 $\mathrm{h}$ period during the second grazing rotation on day 38 of the trial. Observations were recorded every 10 minutes on all animals during daylight and every 15 minutes at night, by six trained observers. Large numbers painted on the sides of the cows were used for identification. Cow bite rate during eating was recorded over two minute periods with a hand-held counter to provide five measurements per day, three between 06:30 - 14:00 hours and two between 15:00 - 18:00 $\mathrm{h}$.

Herbage DM intake was estimated indirectly from animal performance results (Pulido and Leaver 2001) in one opportunity during the experiment as follows:

Herbage DM intake $\left(\mathrm{kg} \mathrm{day}^{-1}\right)=$ $\left(\mathrm{ME}_{\mathrm{m}}+\mathrm{ME}_{\mathrm{my}}+\mathrm{ME}_{\mathrm{lwc}}+\mathrm{ME}_{\mathrm{g}}\right)-(\mathrm{ConcME}+$ silageME$)$ herbageME

Where; $\mathrm{ME}_{\mathrm{m}} \mathrm{ME}_{\mathrm{my}}$ and $\mathrm{ME}_{\mathrm{lwc}}$ are the $\mathrm{ME}$ requirements for maintenance, milk yield and live weight change, respectively (AFRC 1993). Conc ME and silage ME is the ME supplied by the concentrate supplement, and herbage ME is the estimated ME concentration of handplucked herbage samples.

Urine spot samples were taken from week 2 to week 8 to estimate rumen microbial growth. Spot urine samples (approximately $10 \mathrm{ml}$ ) were collected for two consecutive days each week at 7:00 $\mathrm{h}$ and 16:00 $\mathrm{h}$, when dairy cows urinated spontaneously or by vulvar stimulation. Daily collections of urine were preserved with sulphuric acid $(10 \% \mathrm{v} / \mathrm{v})$ to maintain a pH below 3 and stored at $20{ }^{\circ} \mathrm{C}$. Urine samples were thawed and a week composite sample was obtained from each cow for analysis of allantoin, uric acid and creatinine (CT) by chromatography (HPLC). Urinary PD was measured as described by Tas and Susenbeth (2007). Urine volume was estimated using creatinine concentration as a marker and assuming a daily creatinine excretion of 26 $\mathrm{mg} \mathrm{kg}^{-1}$ of BW-0.75 (Tas and Susenbeth 2007). Microbial CP (MCP) synthesis and microbial efficiency were calculated via total excretion of $\mathrm{PD}$ (allantoin + uric acid) using equations proposed by Chen and Orskov (2003). It was assumed that an endogenous contribution of total excretion of PD was $385 \mathrm{mmol} / \mathrm{kg}^{0.75} \mathrm{Chen}$ and Gomes (1992). Thereafter, the amount of microbial $\mathrm{N}$ was estimated as shown in Eq. [1] and [2] assuming $70 \mathrm{mg}$ of $\mathrm{N} \mathrm{mmol}^{-1}$ of PD, microbial purine digestibility of 0.83 , ratio of purine $\mathrm{N}$ to total $\mathrm{N}$ in mixed microbial biomass of 0.116 , and the absorptive efficiency of purines of 0.85 (Valadares et al 1999):

$$
\begin{aligned}
\text { Eq. } 1 ; \mathrm{MN} & =\mathrm{X} \times 70 /(0.83 \times 0.116 \times 1.000) \\
\text { Eq. } 2 ; \mathrm{X} & =\left[\mathrm{Y}-\left(0.385 \times \mathrm{BW}^{0.75}\right)\right] / 0.85
\end{aligned}
$$

Where $\mathrm{MN}$ is the amount of microbial $\mathrm{N} \mathrm{g} \mathrm{d}^{-1}$; $\mathrm{X}$ is the amount of microbial PD absorbed, mmol d ${ }^{-1}$; $\mathrm{BW}$ is the body weight in kilograms and $\mathrm{Y}$ is the amount of PD excreted in $\mathrm{mmol} \mathrm{d}^{-1}$. 
Coccygeal blood samples were obtained weekly from week 2 onwards after afternoon milking using a vacutainer containing sodium heparin and sodium fluoride anticoagulant. Plasma was separated after centrifugation, frozen and analyzed for non-esterified fatty acid (NEFA) and plasma urea-N using a Wierner, Metrolab $2300 ®$ autoanalyzer.

\section{STATISTICAL ANALYSIS}

This study was a randomized block design with a $2 \times 3$ factorial arrangement of treatments using Repeat Measures Analysis of Variance. The analyses of the variances were carried out using the PROC MIXED procedure of SAS. The statistical model was:

$\gamma_{i j k l m}=\mu+P_{i}+C_{j}+W_{k}+A_{l}(P C)_{i j}+\varepsilon_{i j k l}$

Where; $\gamma_{i j k l m}=$ dependent variables (milk production, $\%$ fat, \% protein, $\mathrm{kg}$ fat, $\mathrm{kg}$ protein, urea, live weight, body condition), $\mu=$ intercept, $P_{i}=$ effect of the $i$ - th pasture offer, $C_{j}=$ effect of the $\mathrm{j}$ - th level of supplementation with concentrate, $W_{k}=$ effect of the k-th week, $A_{l}=$ random effect of the $\mathrm{m}$-th animal, $(P C)_{i j}=$ effect of the interaction between pasture offer, level of supplementation with concentrate, $\varepsilon_{i j k l}=$ residual of the model.

\section{RESULTS}

\section{WEATHER CONDITIONS}

The mean temperature during the study was $10.3 \pm$ $2.78{ }^{\circ} \mathrm{C}$, the accumulated rainfall during the trial was
$455 \mathrm{~mm}$, a $21 \%$ lower than the historical value $(576 \mathrm{~mm})$. However, the weather conditions for temperature and rainfall registered during the previous summer caused a decrease in the growth rate and recovery of the pasture, as well as less herbage mass during the autumn.

\section{GRAZING MANAGEMENT AND PASTURE AND SUPPLEMENT QUALITY}

During the experiment, the offered daily pasture allowance per cow was 20 and $30 \mathrm{~kg}$ of DM cow ${ }^{-1}$ day $^{-1}$, measured at ground level for the low and high treatments, respectively. Pre-grazing herbage mass averaged $1,673 \mathrm{~kg}$ $\mathrm{DM} \mathrm{ha}^{-1}$ (above ground level), for the two pasture allowances. Post-grazing herbage mass averaged 1,372 \pm 100 and $1,241 \pm \mathrm{SD} 82 \mathrm{~kg} \mathrm{DM} \mathrm{ha}^{-1}$, for the high and low herbage allowance, respectively. The nutritive value (table 1) of the pre-grazing pastures was typically high quality, with high values of CP (263 g kg-1 DM), low DM (144 $\mathrm{g} \mathrm{kg}^{-1}$ $\mathrm{DM}$ ), and ME $2.66 \mathrm{Mcal} \mathrm{kg}^{-1} \mathrm{DM}$. The concentrate had low protein concentration $\left(127 \mathrm{~g} \mathrm{~kg}^{-1} \mathrm{DM}, \mathrm{CP}\right)$ and fiber concentration (146 g kg-1 DM, NDF) and the silage offered moderate quality with $170 \mathrm{~g} \mathrm{~kg}^{-1} \mathrm{DM}, 123 \mathrm{~g} \mathrm{~kg}^{-1}$ of CP and $645 \mathrm{~g} \mathrm{~kg}^{-1} \mathrm{DM}$ of NDF.

\section{MILK PRODUCTION AND ANIMAL PERFORMANCE}

Mean yield and composition of dairy cows grazing high pasture allowance (HPA) and low pasture allowance (LPA) of permanent pasture (high (HPA) and low pasture allowance, respectively) and supplemented with three levels of concentrate are presented in table 2. Milk yield

Table 1. Chemical composition of the pasture and supplements offered throughout the study.

Composición química de la pradera y de los suplementos ofrecidos durante el estudio.

\begin{tabular}{|c|c|c|c|c|c|c|c|c|}
\hline & \multicolumn{8}{|c|}{ Feeds } \\
\hline & \multicolumn{4}{|c|}{ Pasture allowance } & \multirow{2}{*}{\multicolumn{2}{|c|}{ Grass silage }} & \multirow{2}{*}{\multicolumn{2}{|c|}{ Concentrate }} \\
\hline & \multicolumn{2}{|c|}{ High } & \multicolumn{2}{|c|}{ Low } & & & & \\
\hline & $\mathrm{X} \pm$ & SD & $\mathrm{X} \pm$ & SD & $\mathrm{X} \pm$ & $\pm \mathrm{SD}$ & $X \pm$ & $\mathrm{SD}$ \\
\hline Number of samples & \multicolumn{2}{|c|}{8} & \multicolumn{2}{|c|}{8} & \multicolumn{2}{|c|}{8} & \multicolumn{2}{|c|}{8} \\
\hline DM (\%) & 14.4 & 2.7 & 13.9 & 3.1 & 18.1 & 1.3 & 86.3 & 0.7 \\
\hline $\mathrm{CP}(\%)$ & 26.3 & 1.5 & 28.5 & 1.4 & 12.2 & 1.4 & 13.6 & 0.2 \\
\hline $\mathrm{ME}(\mathrm{Mcal} / \mathrm{kg} \mathrm{DM})$ & 2.66 & 0.13 & 2.64 & 0.13 & 2.20 & 0.04 & 3.15 & 0.01 \\
\hline $\operatorname{NDF}(\%)$ & 39.8 & 3.3 & 38.6 & 1.6 & 64.1 & 0.7 & 18.4 & 0.5 \\
\hline $\operatorname{ADF}(\%)$ & 26.8 & 1.5 & 26.6 & 1.4 & 42.4 & 1.1 & 7.6 & 1.1 \\
\hline $\operatorname{IVD}(\%)$ & 73.2 & 4.0 & 72.5 & 4.0 & 59.0 & 1.3 & 87.9 & 0.1 \\
\hline $\operatorname{Ash}(\%)$ & 10.0 & 1.4 & 11.1 & 2.5 & 6.0 & 0.1 & 3.4 & 0.3 \\
\hline $\mathrm{pH}$ & - & - & - & - & 4.2 & 0.1 & - & - \\
\hline $\mathrm{N}-\mathrm{NH}_{3}$ & - & - & - & - & 12.7 & 0.4 & - & - \\
\hline
\end{tabular}

$\mathrm{DM}=$ dry matter; $\mathrm{CP}=$ crude protein; $\mathrm{ME}=$ metabolizable energy; $\mathrm{NDF}=$ neutral detergent fiber; $\mathrm{ADF}=$ acid detergent fiber; $\mathrm{IVD}=$ in vitro digestibility; $\mathrm{SD}=$ standard deviation. 
was not statistically different between cows grazing HPA and LPA. Moreover, the values, milk persistency, fat and milk urea showed no significant differences between the two pasture allowances $(\mathrm{P}>0.05)$. The increase in pasture allowance significantly increased the amount and concentration of milk protein (table 2), without differences regarding milk production, fat content and concentration, the lactation persistence, or milk urea concentration $(\mathrm{P}>0.05)$.

The concentrations of milk fat and protein did not change when the level of supplementation increased. Supplementation with concentrate increased $(\mathrm{P}<0.05)$ milk, fat and protein yields. The concentration of milk urea decreased $(\mathrm{P}<0.001)$ with the highest level of supplementation ( 0 to $6 \mathrm{~kg}$ of concentrate $\left.{ }^{-1} \mathrm{cow}^{-1}\right)$. Milk fat and milk protein yield showed similar trends as the milk yield.

Pasture DM intake and total DM intake (table 3) increased allong with pasture allowance, from $6.7 \mathrm{~kg}^{-1}$ day ${ }^{-1}$ for LPA to $8.8 \mathrm{~kg}^{-1}$ day $^{-1}$ for HPA and from $13.5 \mathrm{~kg}^{-1}$ day $^{-1}$ for LPA to $15.6 \mathrm{~kg}^{-1}$ day $^{-1}$ for HPA, respectively $(\mathrm{P}<0.05)$. The increase of pasture allowance resulted in a total increase of grazing time of $112 \mathrm{~min} \mathrm{day}^{-1}$, a decrease of the bite rate of 8 bites $\mathrm{min}^{-1}$ and an increase of the pasture allowance tended to increase total feed intake (table 3).

Concentrate supplementation significantly $(\mathrm{P}<0.05)$ increased TDMI, from $13.8 \mathrm{~kg}$ of DM cow ${ }^{-1} \mathrm{day}^{-1}$ for the not supplemented cows to $15.6 \mathrm{~kg}$ of DM cow ${ }^{-1} \mathrm{day}^{-1}$ for the cows receiving $6 \mathrm{~kg}$ of concentrate per day $(\mathrm{P}<0.05)$.
Pasture DMI decreased with concentrate supplementation from $9.6 \mathrm{~kg}$ of DM cow ${ }^{-1}$ day $^{-1}$ for 0 concentrate to an average of $6.9 \mathrm{~kg}$ of DM cow ${ }^{-1}$ day $^{-1}$ when concentrate was fed $(P<0,05)$. There was no significant effect of the increase of concentrate supplementation on the time destined to grazing. The bite rate was not affected by supplementation with concentrate.

An interaction was observed between pasture allowance and concentrate supplement for the time destined to ruminating $(\mathrm{P}<0.05)$, with less time for ruminating in cows grazing high pasture allowance which were supplemented with $0 \mathrm{~kg}$ of concentrate.

Pasture allowance had no effect on body weight, body weight gain and body condition score. An increased pasture allowance tended to increased the body condition score (BCS) $(\mathrm{P}=0.067)$. The supplementation with up to $6 \mathrm{~kg}$ of concentrate did not have an effect on the live weight change and body condition change $(\mathrm{P}>0.05)$.

\section{EXCRETION OF PURINE DERIVATIVES AND BLOOD PROFILES}

Pasture allowance increased $(\mathrm{P}<0.05)$ concentrations of allantoin, and $\mathrm{PD} / \mathrm{CT}$ ratio and decreased uric acid of urine $(\mathrm{P}<0.05)$ were obtained when increasing pasture allowance. Cows grazing on a HPA had a similar microbial nitrogen efficiency $\mathrm{MN}$ than the cows grazing LPA. The concentrations of allantoin, uric acid and creatinine in urine and the $\mathrm{PD} / \mathrm{CT}$ ratio were not affected by

Table 2. Milk yield and milk composition of dairy cows grazing two pasture allowances and supplemented with three levels of concentrate. Producción y composición de leche de vacas lecheras pastoreando dos ofertas de pradera y suplementadas con tres cantidades de concentrado.

\begin{tabular}{|c|c|c|c|c|c|c|c|}
\hline & \multirow{3}{*}{$\begin{array}{l}\text { Milk yield } \\
\left(\mathrm{kg} \mathrm{day}^{-1}\right)\end{array}$} & \multirow{3}{*}{$\begin{array}{c}\text { Milk persistency } \\
\qquad\left(\mathrm{kg} \mathrm{day}^{-1}\right)\end{array}$} & \multicolumn{4}{|c|}{ Milk Composition } & \multirow{3}{*}{$\begin{array}{c}\text { Milk } \\
\text { Urea } \\
\left(\mathrm{mmol} \mathrm{L}^{-1}\right)\end{array}$} \\
\hline & & & Fat & Protein & Fat & Protein & \\
\hline & & & $(\%)$ & $(\%)$ & $\left(\mathrm{kg} \mathrm{day}^{-1}\right)$ & $\left(\mathrm{kg} \mathrm{day}^{-1}\right)$ & \\
\hline \multicolumn{8}{|c|}{ Pasture allowance } \\
\hline High & $19.4^{\mathrm{a}}$ & $-0.055^{a}$ & $3.78^{\mathrm{a}}$ & $3.21^{\mathrm{a}}$ & $0.73^{\mathrm{a}}$ & $0.62^{\mathrm{a}}$ & $7.8^{\mathrm{a}}$ \\
\hline Low & $18.0^{\mathrm{a}}$ & $-0.095^{a}$ & $3.59^{\mathrm{a}}$ & $3.02^{b}$ & $0.64^{\mathrm{a}}$ & $0.54^{\mathrm{b}}$ & $7.7^{\mathrm{a}}$ \\
\hline SED & 0.87 & 0.0152 & 0.11 & 0.05 & 0.03 & 0.02 & 0.29 \\
\hline Significance & 0.266 & 0.074 & 0.238 & $<0.022$ & 0.063 & 0.031 & 0.859 \\
\hline \multicolumn{8}{|c|}{ Concentrate supplementation ( $\mathrm{kg} \mathrm{DM}$ cow $^{-1}$ day $\left.^{-1}\right)$} \\
\hline 0 & $15.1^{\mathrm{b}}$ & $-0.138^{b}$ & $3.90^{\mathrm{a}}$ & $3.10^{\mathrm{a}}$ & $0.58^{\mathrm{b}}$ & $0.47^{\mathrm{c}}$ & $8.7^{\mathrm{a}}$ \\
\hline 2.6 & $19.2^{\mathrm{a}}$ & $-0.063^{a}$ & $3.53^{\mathrm{a}}$ & $3.08^{\mathrm{a}}$ & $0.68^{a b}$ & $0.58^{\mathrm{b}}$ & $7.9^{\mathrm{a}}$ \\
\hline 5.2 & $21.7^{\mathrm{a}}$ & $-0.024^{a}$ & $3.63^{\mathrm{a}}$ & $3.18^{\mathrm{a}}$ & $0.79^{a}$ & $0.68^{a}$ & $6.6^{\mathrm{b}}$ \\
\hline SED & 1.06 & 0.0186 & 0.14 & 0.06 & 0.04 & 0.03 & 0.35 \\
\hline Significance & $<0.001$ & $<0.001$ & 0.172 & 0.470 & $<0.007$ & $<0.001$ & $<0.002$ \\
\hline \multicolumn{8}{|c|}{ Interactions significance } \\
\hline $\mathrm{PA} \times \mathrm{CS}$ & 0.851 & 0.596 & 0.367 & 0.887 & 0.342 & 0.689 & 0.080 \\
\hline
\end{tabular}

Means within a column with different superscripts differ $(\mathrm{P}<0.05)$. PA x CS = interaction between pasture allowance $(\mathrm{PA})$ and concentrate supplementation (CS).

$\mathrm{SED}=\mathrm{SED}$ of the difference. 
Table 3. Grazing behaviour and dietary intake of dairy cows $(n=30)$ feed on two herbage allowances and supplemented with three levels of concentrate.

Comportamiento alimenticio y consume de alimento de vacas lecheras alimentadas con dos ofertas de pradera y suplementadas con tres cantidades de concentrado.

\begin{tabular}{|c|c|c|c|c|c|c|}
\hline & \multicolumn{3}{|c|}{ Dry matter intake } & \multicolumn{2}{|c|}{ Grazing behaviour } & \multirow[b]{2}{*}{ Bite rate } \\
\hline & Pasture & Grass silage & TDMI $^{1}$ & Grazing time & Ruminating time & \\
\hline & $\left(\mathrm{kg}\right.$ day- $\left.{ }^{-1}\right)$ & $\left(\mathrm{kg}\right.$ day- $\left.{ }^{1}\right)$ & $\left(\mathrm{kg}\right.$ day- $\left.-^{1}\right)$ & $\left(\min\right.$ day $\left.^{-1}\right)$ & $\left(\min\right.$ day $\left.^{-1}\right)$ & $\left(\min\right.$ day $\left.^{-1}\right)$ \\
\hline \multicolumn{7}{|l|}{ Pasture allowance } \\
\hline High & $8.8^{\mathrm{a}}$ & 4.2 & $15.6^{\mathrm{a}}$ & $411^{\mathrm{a}}$ & $393^{a}$ & $59^{b}$ \\
\hline Low & $6.7^{\mathrm{b}}$ & 4.2 & $13.5^{\mathrm{b}}$ & $299^{b}$ & $423^{a}$ & $67^{\text {a }}$ \\
\hline SED & 0.42 & - & 0.42 & 18.3 & $14.4^{\mathrm{a}}$ & 1.8 \\
\hline Significance & $<0.002$ & - & $<0.003$ & $<0.001$ & 0.156 & 0.003 \\
\hline \multicolumn{7}{|c|}{ Concentrate supplementation ( $\mathrm{kg} \mathrm{DM} \mathrm{cow}{ }^{-1}$ day $^{-1}$ ) } \\
\hline 0 & $9.6^{\mathrm{a}}$ & 4.2 & $13.8^{\mathrm{a}}$ & $373^{a}$ & $395^{a}$ & $61^{\mathrm{a}}$ \\
\hline 2.6 & $7.6^{\mathrm{b}}$ & 4.2 & $14.4^{\mathrm{a}}$ & $359^{\mathrm{a}}$ & $409^{\mathrm{a}}$ & $62^{a}$ \\
\hline 5.2 & $6.2^{\mathrm{b}}$ & 4.2 & $15.6^{\mathrm{a}}$ & $332^{a}$ & $421^{\mathrm{a}}$ & $66^{\mathrm{a}}$ \\
\hline SED & 0.51 & - & 0.51 & 22.4 & 17.6 & 2.2 \\
\hline Significance & $<0.001$ & - & $<0.050$ & 0.455 & 0.592 & 0.272 \\
\hline \multicolumn{7}{|c|}{ Interactions significance } \\
\hline $\mathrm{PA} \times \mathrm{CS}$ & 0.889 & - & 0.889 & 0.520 & 0.021 & 0.977 \\
\hline
\end{tabular}

${ }^{1}$ TDMI: total DM intake. Means within a column with different superscripts differ $(\mathrm{P}<0.05) . \mathrm{SED}=\mathrm{SE}$ of the difference. $\mathrm{PA} \times \mathrm{CS}=$ interaction between pasture allowance and concentrate supplementation.

the level of supplement concentrate used. In this study the efficiency of microbial nitrogen synthesis $(\mathrm{MN})$ was different among treatments that were supplemented with concentrate (34.6, 32.3 and 29.2 $\mathrm{g} \mathrm{MN} \mathrm{kg}^{-1} \mathrm{MOI}$ for the groups supplemented with $0,2.6$ and $5.2 \mathrm{~kg}$ of concentrate, respectively).

The concentrations of NEFA increased $(\mathrm{P}<0.055)$ due to grazing a lower PA. The plasma urea concentration were higher with a high PA $(\mathrm{P}<0.05)$ and, for both pasture allowances. The plasma NEFA, urea and albumin concentrations decreased $(\mathrm{P}<0.05)$ throughout the supplementation with 3 and $6 \mathrm{~kg}$ of concentrate. An interaction was observed between pasture allowance and supplemented with concentrate for the blood urea, with a lower concentration for the $6 \mathrm{~kg}$ of the concentrate supplemented and dairy cows grazing HPA.

\section{DISCUSSION}

\section{GRAZING MANAGEMENT AND PASTURE AND SUPPLEMENT QUALITY}

Pasture conditions during the autumn are quite variable because they are directly related to weather conditions during summer and early autumn. In the present study, the availability of pasture mass was penalised due to a low rainfall before the experiment and at the beginning of the trial. As expected, pre-grazing pasture charac- teristics were similar for the all treatments. Pre-grazing herbage mass averaged $1673 \mathrm{~kg} \mathrm{DM} \mathrm{ha}^{-1}$ (above ground level), for the two pasture allowances. This was similar to the $1,800 \mathrm{~kg} \mathrm{DM} \mathrm{ha}^{-1}$ (above ground level), of pasture mass reported by Hernandez-Mendo and Leaver (2004) and Pulido et al (2010) but, higher than the amount reported by Perez-Prieto et al (2011). In the dairy production systems of this geographical region, where animals graze all year round, having to wait for a pre-grazing herbage mass similar to the spring conditions reported by Pulido et al (2009) would mean keeping the animals without grazing for long periods of time, which is not possible under these conditions. Post-grazing herbage mass averaged $1372 \pm 100$ and $1241 \pm$ SD $82 \mathrm{~kg} \mathrm{DM} \mathrm{ha}^{-1}$, for the high and low herbage allowance, respectively. The area offered daily in the low pasture allowance $\left(124 \mathrm{~m}^{2} \mathrm{cow}^{-1}\right)$ was $29.5 \%$ less than in the high pasture allowance, which is similar to the average reported by Pulido et al (2010) and higher in $30 \mathrm{~m}^{2}$ than in the report of Pérez-Prieto et al (2011). Similar pasture allowances were used in spring grazing by (Pulido et al 2009) but with higher pre-grazing herbage mass. According to Sairanen et al (2006), a pre-grazing herbage mass lower than $2700 \mathrm{~kg} \mathrm{DM} \mathrm{ha}^{-1}$ limits pasture intake without regard to the given surface, strongly increasing the difficulty of biting the grass.

In this study, the nutritive value (table 1) of the pregrazing pastures was typically high quality, when compared to the ones reported by Perez-Prieto et al (2011). 
These values are representative of autumn pastures in southern Chile (Anrique et al 2008).

\section{MILK PRODUCTION AND ANIMAL PERFORMANCE}

The effect of the two pastures allowances, the three levels of supplementation with concentrate on milk production and composition are shown in table 2 . The values for milk production, milk persistency, fat and milk urea showed no differences between the two pasture allowances $(\mathrm{P}<0.05)$. The lack of response in milk production could be related to the similar intake of nutrients, in quantity and quality, obtained from the two pasture allowances that were insufficient to cause an increase in the total DM intake (table 3). Perez-Prieto et al (2011) found an increase of $2.3 \mathrm{~kg}$ of pasture intake when an allowance of 32 of DM kg cow ${ }^{-1}$ day $^{-1}$ was given, but in their trial the pre-grazing herbage mass was higher $(2300$ $\mathrm{kg}$ of organic matter (OM) ha- ${ }^{-1}$ above ground level) than the ones in this study.

The results show that the increase in pasture allowance significantly increased the amount and concentration of milk protein, without differences regarding milk production, fat content and concentration, the lactation persistence, or plasma urea concentration $(\mathrm{P}<0.05)$. However, a higher pasture allowance would prevent from an abrupt fall in the milk yield of the cows and therefore there is a tendency towards a higher persistency $(\mathrm{P}=0.07)$, similar to the previously described (Pulido et al 2010). It is possible that the cows receiving a low pasture allowance might have been using their body reserves to compensate for the lower DM intake and therefore reduce the impact in milk production (McEvoy et al 2008), causing a decrease in body condition and in the live weight of these cows. Kennedy et al (2008) also did not find an effect of the pasture allowance on milk production in cows at the beginning and middle of lactation (40,80 and 120 days in milk), evaluating the following pasture offers: 13,16 and $19 \mathrm{~kg}$ of DM cow-1 day-1, measured $>4 \mathrm{~cm}$ height. The milk yield and concentration of milk fat were not modified by the pasture allowance. These results could be explained because the NDF intake was not a limiting factor, with values between 39 and $47 \%$ of the total diet and higher than the 25\% pointed out by Stockdale (1999). When evaluating the fat production $\left(\mathrm{kg} \mathrm{cow}^{-1} \mathrm{day}^{-1}\right)$ Kennedy et $a l$ (2007) and Kennedy et al (2008) did not find differences, just as in this study. The increase in pasture allowance caused higher concentrations of milk protein, similar to the reports of Delaby et al (2001) and McEvoy et al (2008), as a consequence of the higher DM and energy intake of the cows. The milk urea (MUN) concentrations were similar among pasture allowances (table 2). Milk urea nitrogen concentrations were higher than those reported by Bargo et al (2002). These differences may have occurred because of a higher $\mathrm{CP}$ content in the autumn pasture, caused by grazing short swards in a vegetative state. Additionally, $\mathrm{NH}_{3}-\mathrm{N}$ use by rumen microbes was not improved when the cows were grazing on contrasting pasture allowances.

Supplementation with concentrate increased $(\mathrm{P}<0.05)$ milk, fat and protein yields. Previous studies have reported yield increases in response to concentrate feeding (Horan et al 2005). Milk yield with 3 and $6 \mathrm{~kg}$ of concentrate was higher (19.2 and $21.7 \mathrm{~kg}$, respectively) than the milk yield of non-supplemented cows $(15.1 \mathrm{~kg})$, in agreement with the reports of Delaby et al (2001), Kennedy et al (2003), Sairanen et al (2006) and McEvoy et al (2008). The marginal yield to the use of concentrate was higher when supplementing with $3 \mathrm{~kg}$ of concentrate (1.3 kg milk kg-1 concentrate) when compared to supplementation with $6 \mathrm{~kg}$ (1.1 kg milk kg-1 of concentrate). These responses were higher than the ones reported by Bargo et al (2003), who found an average response of $1 \mathrm{~kg}$ of milk kg${ }^{-1} \mathrm{DM}$ of concentrate, with up to $10 \mathrm{~kg}$ of supplementation. Stockdale (1999) reported a higher milk yield response (1.1 kg kg${ }^{-1}$ of DM of concentrate) for the summer-autumn season, supplementing with $5 \mathrm{~kg}$ of concentrate. The lower marginal response of the last $3 \mathrm{~kg}$ of concentrate at the highest level of supplementation could be due to the fact that the cows would have increased the energy spent in other physiological functions (Kuoppala et al 2004); in this case to reduce the milk urea and to improve the persistence of lactation (Bargo et al 2002, Pulido and Leaver 2003). The supplementation with concentrate caused a linear increase of the fat and milk protein yield of $0.1 \mathrm{~kg}$ per $\mathrm{kg}^{-1}$ of supplement due to the higher milk yield, as reported by Delaby et al (2001), Bargo et al (2002), Sairanen et al (2006) and Kennedy et al (2007). The concentrations of milk fat and protein did not change when the level of supplementation increased, maybe as a consequence of the adequate fiber intake and moderate intake of concentrate. This finding agrees with Delaby et al (2003), Kennedy et al (2003) and McEvoy et al (2008). The concentration of milk urea decreased $(\mathrm{P}<0,001)$ with the highest level of supplementation reaching values of $6.6 \mathrm{mmol} \mathrm{L}^{-1}$. This could be explained by the highest intake of energy from the carbohydrates in this treatment (Bargo et al 2002, Sairanen et al 2006), the better energyprotein synchrony at ruminal level and a reduction in the protein content of the diet, producing a reduction in the ruminal content of ammonia. However, the decrease of urea per $\mathrm{kg}$ of concentrate allowance was higher in this study $\left(0.38 \mathrm{mmol} \mathrm{l}^{-1} \mathrm{~kg}^{-1}\right)$ when compared with the reports of Bargo et al (2002) $\left(0.09 \mathrm{mmol}^{-1}\right)$ and Sairanen et al (2006) $\left(0.06 \mathrm{mmol} \mathrm{l}^{-1} \mathrm{~kg}^{-1}\right)$, maybe as a result of the different nutritional composition of the pastures used.

The results of this study, just like the reports of Delaby et al (2001), Kennedy et al (2007) and McEvoy et al (2008), did not show a significant interaction $(\mathrm{P}<0.05)$ between the supplementation with concentrate and the pasture allowance on milk production and its composition. According to Bargo et al (2002), it is possible to 
find an interaction under conditions of larger differentials of pasture allowance (25 vs. $40 \mathrm{~kg}$ DM ground level) and supplementation with concentrate ( 0 vs. $8.6 \mathrm{~kg})$, situation that did not happen in this experiment.

The better feeding conditions of the cows on a high pasture allowance allowed an average increase of live weight of $0.336 \mathrm{~kg} \mathrm{day}^{-1}$, with a trend towards increasing the BCS $(\mathrm{P}=0.067)$ and improving the persistence of lactation $(\mathrm{P}=0.074)$. In contrast, the cows with a lower pasture allowance were less consistent causing losses of $-0.121 \mathrm{~g} \mathrm{day}^{-1}$ in their body weight (table 4$)$. The supplementation with up to $6 \mathrm{~kg}$ of concentrate did not have effect on the live weight change and body condition change, results that are similar to those reported by Pulido and Leaver (2001), Bargo et al (2002) and Kennedy et al (2002), who also did not find a clear effect in cows of medium and high milk yield potential.

Feed intake data are presented in the table 3. During the experiment, cows grazing the low PA had lower pasture $(\mathrm{P}<0.05,-0.8 \mathrm{~kg})$ and total DM intake. On the low mass pasture, dairy cows tried to maintain pasture intake by increasing grazing time, but in the presence of a very short sward cows are unable to fully compensate the reduction of intake rate and the total daily intake is reduced (Pulido and Leaver 2001 and Perez-Prieto et al 2011). In this experiment, the increase of pasture allowance resulted in a total increase of grazing time of $112 \mathrm{~min} \mathrm{day}^{-1}$, a decrease of the bite rate of 8 bites $\mathrm{min}^{-1}$ and an increase of the total food in- take (Table 3). The use of supplementary preserved forages such as grass silage can be used to increase the total DM intake, when offered for a short period each day as a buffer feed for grazing dairy cows fed in low-mass pasture (Phillips and Leaver 1985). However, the response depends on pasture availability, the relative nutritive values of grazed herbage and supplementary forage, and the time of access to each feed (Hernandez-Mendo and Leaver 2004, PerezPrieto et al 2011). Time at pasture was normally restricted and the time available for grazing was replaced with time available for eating grass silage and concentrate. Under these tough grazing conditions, total DM intake is generally insufficient to meet higher intakes and milk yields.

Concentrate supplementation $(\mathrm{P}<0.05)$ increased TDMI, from $13.8 \mathrm{~kg}$ of DM cow ${ }^{-1}$ day $^{-1}$ for the not supplemented cows to $15.6 \mathrm{~kg}$ of DM cow ${ }^{-1}$ day $^{-1}$ for the cows receiving $5.2 \mathrm{~kg}$ DM of concentrate per day. Pasture DMI decreased with concentrate supplementation from $9.6 \mathrm{~kg}$ of DM cow ${ }^{-1} \mathrm{day}^{-1}$ for 0 concentrate to an average of $6.2 \mathrm{~kg}$ of DM cow ${ }^{-1}$ day $^{-1}$ when concentrate was fed $(\mathrm{P}<0.05)$. Despite the supplementation with silage, pasture intakes can be considered low since it is possible that the availability (surface given per animal) and pasture allowance may have restricted the intake. On the other hand, the silage may have limited the intake of pasture. Therefore, silage was given additionally to act as a buffer, to ensure the animals would be provided with sufficient amounts of DM (Phillips and Leaver 1985).

Table 4. Body weight and body condition score of dairy cows grazing two pasture allowances and supplemented with three levels of concentrate.

Peso vivo y condición corporal de vacas lecheras pastoreando dos ofertas de pradera y suplementadas con tres cantidades de concentrado.

\begin{tabular}{|c|c|c|c|c|}
\hline & \multicolumn{2}{|c|}{ Body weight } & \multicolumn{2}{|c|}{ Body condition score } \\
\hline & $\begin{array}{c}\text { Initial } \\
\left(\mathrm{kg} \mathrm{day}^{-1}\right)\end{array}$ & $\begin{array}{c}\text { Gain } \\
\left(\mathrm{kg} \mathrm{day}^{-1}\right)\end{array}$ & $\begin{array}{l}\text { Initial } \\
\text { (points) }\end{array}$ & $\begin{array}{c}\text { Change } \\
\left(\text { points period }^{-1}\right)\end{array}$ \\
\hline \multicolumn{5}{|l|}{ Pasture allowance } \\
\hline High & $509^{a}$ & $0.336^{\mathrm{a}}$ & $2.80^{\mathrm{a}}$ & $0.107^{\mathrm{a}}$ \\
\hline Low & $506^{\mathrm{a}}$ & $-0.121^{b}$ & $2.87^{\mathrm{a}}$ & $-0.127^{\mathrm{a}}$ \\
\hline SED & 16.4 & 0.096 & 0.11 & 0.084 \\
\hline Significance & 0.866 & $<0.004$ & 0.531 & 0.067 \\
\hline \multicolumn{5}{|c|}{ Concentrate supplementation (kg DM cow ${ }^{-1}$ day $\left.^{-1}\right)$} \\
\hline 0 & $492^{\mathrm{a}}$ & $0.170^{\mathrm{a}}$ & $2.85^{\mathrm{a}}$ & $-0.110^{a}$ \\
\hline 2.6 & $510^{\mathrm{a}}$ & $-0.017^{\mathrm{a}}$ & $2.77^{\mathrm{a}}$ & $0.000^{\mathrm{a}}$ \\
\hline 5.2 & $521^{\mathrm{a}}$ & $0.169^{\mathrm{a}}$ & $2.84^{\mathrm{a}}$ & $0.080^{\mathrm{a}}$ \\
\hline SED & 20.1 & 0.1176 & 0.14 & 0.1039 \\
\hline Significance & 0.583 & 0.449 & 0.902 & 0.447 \\
\hline \multicolumn{5}{|c|}{ Interactions significance } \\
\hline $\mathrm{PA} \times \mathrm{CS}$ & 0.412 & 0.063 & 0.811 & 0.319 \\
\hline
\end{tabular}

${ }^{1}$ Means within a column with different superscripts differ $(\mathrm{P}<0.05)$. PA x $\mathrm{C}=$ interaction between pasture allowance and concentrate supplementation; $\mathrm{PA} \times \mathrm{S}=$ interaction between pasture allowance and concentrate supplementation. $\mathrm{SED}=\mathrm{SE}$ of the difference. Body condition score $=$ Five point scale $(1=$ thin and $5=$ fat $)$ 
In order to satisfy its nutritionals needs under the circumstances imposed by the pasture, management and environment, the grazing dairy cow responds by adjusting its eating behaviour in terms of eating time, bite rate, chewing rate, bite mass, and intake rate. The grazing time increased to $112 \mathrm{~min}$ day $^{-1}$ when given a high pasture allowance. This increase agrees with a higher intake obtained by the cows in this grazing condition (table 3 ). According to Peyraud et al (1996), the lower grazing time on low-mass pastures is a consequence of dairy cows ceasing grazing due to a physical limitation imposed by the pasture, in that they cannot easily bite the lower height of the pasture. The modification in the eating behaviour could be observed in the cows grazing on the low pasture allowance $\left(1,621 \mathrm{~kg} \mathrm{ha}^{-1}\right)$, showing lower grazing time than those grazing on the high pasture allowance.

There was no effect with the increase of concentrate supplementation on the time destined to grazing. However, the estimated intake rate of pasture DM (table 3 ) was lower for the supplemented group (25.7, 21.2 and $18.7 \mathrm{~g} \mathrm{DM}$ $\min ^{-1}$, for 0,3 and $6 \mathrm{~kg}$ of supplementation, respectively) and despite this situation, a modification of the behavior pattern after the morning milking was observed, which could be caused by the fact that the animals were not eating silage during this period. The lack of effect of supplementation with concentrate on grazing time could be explained by a social effect, where Phillips (1993) suggests that supplementation also affects non-supplemented cows in cases where they were grazing together, such as decreasing their grazing time or, the intake speed in supplemented cows. Although Delaby et al (2003) agree with this study, a considerable number of authors (Pulido and Leaver 2001, Bargo et al 2003 and Delaby et al 2003) show decreasing grazing times under conditions of generous pasture availability in spring. The bite rate was not affected by supplementation with concentrate, just like in the reports of Bargo et al (2002) but opposed to that of Pulido and Leaver (2001). In this regard, Pulido and Leaver (2003) point out that it is possible to expect a decrease in bite rate of cows with supplementation levels that are higher than $6 \mathrm{~kg} \mathrm{cow}^{-1}$ accompanied of high pasture allowances, as a result of these animals having a lack of interest on grazing.

\section{EXCRETION OF PURINE DERIVATIVES AND BLOOD PROFILES}

The main effects of the pasture allowance and the concentrate supplementation on purines derivatives/creatinine $(\mathrm{PD} / \mathrm{CT})$ ratio in spot urine samples are shown in table 5. Higher concentrations of allantoin, purine derivatives excretion $(\mathrm{PDe})$ and $\mathrm{PD} / \mathrm{CT}$ ratio $(\mathrm{P}<0.05)$ were obtained when increasing pasture allowance. Since allantoin is the PD contained in highest proportion in urine, it could suggest that the other parameters would

Table 5. Urine and blood metabolites of dairy cows $(\mathrm{N}=30)$ grazing on two pasture allowances and supplemented with three levels of concentrate.

Metabolitos urinarios y sanguíneos de vacas lecheras pastoreando dos ofertas de pradera y suplementadas con tres cantidades de concentrado.

\begin{tabular}{|c|c|c|c|c|c|c|c|}
\hline & \multicolumn{4}{|c|}{ Urine } & \multicolumn{3}{|c|}{ Blood } \\
\hline & $\begin{array}{l}\text { Allantoin } \\
\left(\mathrm{mmoL} \mathrm{d}^{-1}\right)\end{array}$ & $\begin{array}{l}\text { Uric Acid } \\
\left(\mathrm{mmoL} \mathrm{d}^{-1}\right)\end{array}$ & $\begin{array}{c}\mathrm{PD} / \mathrm{CT} \\
\mathrm{mmol} \mathrm{L} \mathrm{d}{ }^{-1}\end{array}$ & $\begin{array}{c}\text { MN } \\
\left(\mathrm{g} \mathrm{MN} \mathrm{kg}^{-1}\right. \\
\mathrm{MOI})\end{array}$ & $\begin{array}{c}\text { NEFA } \\
\left(\mu \mathrm{mol} \mathrm{L}{ }^{-1}\right)\end{array}$ & $\begin{array}{c}\text { Urea } \\
\left.(\mathrm{mmol} \mathrm{L})^{-1}\right)\end{array}$ & $\begin{array}{c}\text { Albumin } \\
\left(\mathrm{g} \mathrm{L}^{-1}\right)\end{array}$ \\
\hline \multicolumn{8}{|l|}{ Pasture allowance } \\
\hline High & $391^{\mathrm{a}}$ & $17.4^{b}$ & $3.7^{\mathrm{a}}$ & $31.2^{\mathrm{a}}$ & $197^{b}$ & $8.4^{\mathrm{a}}$ & $35.5^{\text {a }}$ \\
\hline Low & $352^{b}$ & $22.8^{\mathrm{a}}$ & $3.4^{\mathrm{b}}$ & $32.9^{\mathrm{a}}$ & $278^{a}$ & $7.6^{b}$ & $33.9^{\mathrm{b}}$ \\
\hline SED & 8.64 & 1.78 & 0.81 & 0.83 & 18.25 & 0.140 & 0.30 \\
\hline Significance & $<0.002$ & $<0.030$ & $<0.017$ & 0.131 & $<0.002$ & $<0.001$ & $<0.001$ \\
\hline \multicolumn{8}{|c|}{ Concentrate supplementation $\left(\mathrm{kg} \mathrm{DM} \mathrm{cow}{ }^{-1}\right.$ day $\left.^{-1}\right)$} \\
\hline 0 & $376^{\mathrm{a}}$ & $24.1^{\mathrm{a}}$ & $3.7^{\text {a }}$ & $34.6^{\mathrm{a}}$ & $308^{a}$ & $9.0^{\mathrm{a}}$ & $36.3^{\text {a }}$ \\
\hline 2.6 & $375^{a}$ & $17.4^{\mathrm{a}}$ & $3.6^{\mathrm{a}}$ & $32.3^{b}$ & $217^{b}$ & $8.0^{\mathrm{b}}$ & $34.7^{b}$ \\
\hline 5.2 & $364^{a}$ & $17.8^{\mathrm{a}}$ & $3.4^{\mathrm{a}}$ & $29.2^{c}$ & $188^{b}$ & $6.9^{\mathrm{c}}$ & $33.1^{\mathrm{c}}$ \\
\hline SED & 10.32 & 2.13 & 0.98 & 1.00 & 22.35 & 0.172 & 0.37 \\
\hline Significance & 0.652 & 0.075 & 0.278 & $<0.001$ & $<0.001$ & $<0.001$ & $<0.001$ \\
\hline \multicolumn{8}{|c|}{ Interactions significance } \\
\hline $\mathrm{PA} \times \mathrm{CS}$ & 0.332 & 0.807 & 0.059 & 0.801 & 0.377 & $<0.000$ & 0.007 \\
\hline
\end{tabular}

$\mathrm{PD} / \mathrm{CT}=$ Purine derivative excretion/creatinine total ratio, $\mathrm{MN}=$ efficiency of microbial nitrogen synthesis NEFA = non esterified fatty acids, Means within a column with different superscripts differ $(\mathrm{P}<0.05)$. PA x CS= interaction between pasture allowance and concentrate supplementation. Means within a column with different superscripts differ $(\mathrm{P}<0.05)$. SED $=\mathrm{SE}$ of the difference. 
probably have a similar behaviour. According to Tas and Susenbeth (2007), increasing the DM intake increases the PD excretion in urine, causing a higher microbial nitrogen flow to the duodenum. This data could explain the differences between allantoin and $\mathrm{PD} / \mathrm{CT}$ ratio, similar to obtained intakes of DM (15.6 kg DM-1 $\mathrm{d}^{-1}$ for high and $13.5 \mathrm{~kg} \mathrm{DM} \mathrm{DM}^{-1} \mathrm{~d}^{-1}$ for low pasture allowance) and to previous studies (Bargo et al 2002, Pulido et al 2010). However, when expressing the efficiency of $\mathrm{MN}$ synthesis as a function of the intake of digestible organic matter ( $\mathrm{g} \mathrm{MN} \mathrm{kg}^{-1}$ organic matter intake, MOI), the level of intake did not show any effect on the efficiency of $\mathrm{MN}$ synthesis for both allowances (31.2 and $32.9 \mathrm{~g} \mathrm{MN} \mathrm{kg}^{-1}$ MOI, for high and low pasture allowance, respectively), indicating that the use of energy did not improve with nitrogen for its deposition as microbial nitrogen.

The concentrations of allantoin, uric acid and creatinine in urine and the PD excretion were not affected by the level of concentrate used. The PD/CT ratio in spot urine samples has been used to indicate relative rates of efficiency in the rumen microbial nitrogen synthesis and to compare diets in dairy cows (Bargo et al 2002). In this study the PD/CT ratio was no difference among treatments (3.7, 3.6 and $3.4 \mathrm{mmol} \mathrm{L}^{-1}$ for the groups supplemented with 0,3 and $6 \mathrm{~kg}$ of concentrate, respectively), and higher than those reported by Pulido et al (2010) and Bargo et al (2002), even though, these authors found an increase of the PD/CT ratio when increasing the level of supplementation. One probable explanation for the lack of effect in microbial protein production among the levels of concentrate supplementation could be the absence of effect of supplementation on the voluntary intake of food, and the type of concentrate used, rich in starch, that would have caused a decrease of the ruminal $\mathrm{pH}$, increasing the energy losses of the microorganisms and as a consequence decreasing the de novo synthesis of amino acids (Russel and Wallace 1997). Bach et al (2005) reported that the optimum yield of microbial growth that would maximize the use of ruminal $\mathrm{N}$ would be of $29.0 \mathrm{~g}$ of $\mathrm{MN} \mathrm{kg}^{-1}$ of rumen degradable organic matter (RDOM), a value that is close to the one obtained in this study $\left(32.0 \mathrm{~g}\right.$ of $\mathrm{MN} \mathrm{kg}^{-1}$ of MOI, table 5) and it is within the ideal interval reported by Dewhurst (2000), in cows that graze high quality pastures.

An indication of the balance between supply and nutrient demand for energy and protein can be obtained by measuring the concentration of blood metabolites. Table 5 shows the plasma concentrations of NEFA, urea and albumin. Energy reserves (fat deposit) are mobilized during the lactation with an energy balance and the extent of lipomobilization can be assessed by measuring the plasma NEFA concentration (Kaneko et al 2008). The concentrations of NEFA increased $(\mathrm{P}<0.05)$ due to grazing a lower PA, maybe as a consequence of the low-mass pasture that decreased the food intake, that is confirmed by the higher loss of live weight in animals grazing a low pasture allowance.
A high urea concentration in the plasma or milk indicates a high rumen ammonia concentration, with excess ammonia passing into the blood stream and being converted to urea in liver. The plasma urea concentration were higher with a high PA $(\mathrm{P}<0.05)$ and, for both pasture allowances, they were kept above the superior reference limit (< $7.0 \mathrm{mmol} \mathrm{L}^{-1}$ ) (Wittwer et al 1999), which indicates an asynchrony between energy/protein in rumen (Pacheco and Waghorn 2007), a high concentration of protein in the diet (table 1). Plasma concentrations of albumin were higher for the cows grazing the high pasture allowance $(\mathrm{P}<0.05)$, suggesting a higher amino acid absorption in gut associated a microbial protein synthesis.

The plasma NEFA, urea and albumin concentrations decreased $(\mathrm{P}<0.05)$ throughout the supplementation with 3 and $6 \mathrm{~kg}$ of concentrate. The cows supplemented with $6 \mathrm{~kg}$ of concentrate decreased their plasma concentrations of NEFA and urea, suggesting an improvement in the energy balance and a better energy/protein ruminal synchrony. However, the average values of plasma urea concentration remain above the superior limit of reference in the 0 and $3 \mathrm{~kg}$ groups, indicating an excessive contribution of rumen degradable proteins. The plasma albumin concentration were lower in groups supplemented with concentrate, and indirectly proportional to milk yield (table 2), which is indicative of stress on protein reserves and use through milk production (Kaneko et al 2008).

High concentrations of plasma urea and low plasma albumin are an indication of an overall shortage of microbial protein due to an insufficient supply of ruminally undegraded protein and an excess of effective ruminally degradable protein that cannot be converted to microbial protein due to a lack of fermentable metabolizable energy (Bach et al 2005). This situation would explain why in this study there was no increase of efficiency in the synthesis of microbial protein even though there was a supplementation with higher amounts of concentrate.

The present study concluded that the increase increase in daily pasture allowance had a positive effect on pasture and total DM intake, but pasture allowance did not increase the milk production and efficiency of microbial protein synthesis. Under scenarios in which pasture is limited (low-mass pasture), high pasture allowance (30 kg of $\mathrm{DM} \mathrm{cow}{ }^{-1} \mathrm{day}^{-1}$ ) implies that cows are requiring larger areas for grazing, although pasture intake is generally insufficient to meet the requirements of dairy cows. Finally, when dairy cows grazing on low-mass pasture are supplemented with $6 \mathrm{~kg}$ of concentrate per day, no matter the pasture allowance, they improved their metabolic balance of energy and protein.

\section{ACKNOWLEDGEMENTS}

The authors would like to thank CONICYT for their support and for awarding Mr. Miguel Ruiz-Albarrán with a $\mathrm{PhD}$ scholarship. We also thank the support of the M1P2 Consor- 
cio Lechero-FIA for awarding Mr. Jorge Schöbitz with a Magister scholarship. This Project was financed by FONDECYT 1070391. Finally, we thank the staff at Experimental Research Station "Vista Alegre" for managing the experimental animals, and to Mr. Eladio Saldivia for the grazing management and assistance with the measurements throughout the study.

\section{REFERENCES}

AFRC, Agricultural and Food Research Council. 1993. Energy and protein requirements of ruminants. An advisory manual prepared by the AFRC Technical Committee on Responses to Nutrients. CAB International, Wallingford, UK.

Anrique R, R Fuchslocher, S Iraira, R Saldaña. 2008. Composición de alimentos para el ganado bovino. Consorcio lechero y Universidad Austral de Chile, Valdivia, Chile.

AOAC, Association of Oficial Analytical Chemical. 1996. Official Methods of Analysis. 16 $6^{\text {th }}$ ed. AOAC, Gaithersburg, USA.

Bach A, S Calsamiglia, MD Stern. 2005. Nitrogen metabolism in the rumen. J Dairy Sci 88, 9-21.

Bargo F, LD Muller, JE Delahoy, TW Cassidy. 2002. Milk response to concentrate supplementation of high producing dairy cows grazing at two pasture allowances. J Dairy Sci 85, 1777-1792.

Bargo F, LD Muller, ES Kolver, JE Delahoy. 2003. Invited Review: Production and digestion of supplemented dairy cows on pasture. J Dairy Sci 86, 1-42.

Chen XB, YK Chen, MF Franklin, ER Orskov, WJ Shand. 1992. The effect of feed intake and body weight on purine derivative excretion and microbial protein supply in sheep. J Anim Sci 70, 1534-1542.

Chen XB, MJ Gomes. 1992. Estimation of microbial protein supply to sheep and cattle based on urinary excretion of purine derivatives: an overview of the technical details. International Feed Resources Unit, Rowett Research Institute, Bucksburn, Aberdeen, UK.

Chen XB, ER Orskov. 2003. Research on urinary excretion of purine derivatives on ruminants: Past, present and future. International Feed Research Unit, Macaulay Land Use Research Institute, Craigiebuckler, Aberdeen, UK.

Chilibroste P, P Soca, DA Mattiauda, O Bentancur, PH Robinson. 2007. Short term fasting as a tool to design effective grazing strategies for lactating dairy cattle: a review. Aust $J$ Exp Agri 47, 1075-1084.

Delaby L, JL Peyraud, R Delagarde. 2001. Effect of the level of concentrate supplementation, herbage allowance and milk yield at turn-out on the performance of dairy cows in mid lactation at grazing. Anim Sci 73, 171-181.

Delaby L, JL Peyraud, JR Peccatte, N Foucher, G Michel. 2003. The effect of two contrasting grazing managements and level of concentrate supplementation on the performance of grazing dairy cows. Anim Res 52, 437-460.

Delahoy JE, LD Muller, JE Delahoy, TW Cassidy, LA Holden. 2003. Supplemental carbohydrates sources for lactating dairy cows on pasture. J Dairy Sci 86, 906-915.

Dewhurst RJ, DR Davies, RJ Merry. 2000. Microbial protein supply from the rumen. Anim Feed Sci Technol 85, 1-21.

Ferguson JD, DT Galligan, N Thomsen. 1994. Principal descriptors of body condition in holstein dairy cattle. J Dairy Sci 77, 2695-2703.
Goering HK, PJ Van Soest. 1970. Forage fiber analysis. ARS/ USD Handbook $\mathrm{N}^{\circ} 379$, USA.

Gonzalez-Ronquillo M, J Balcells, A Belenguer, C Castrillo, M Mota. 2004. A comparison of purine derivates excretion with conventional methods as indices of microbial yield in dairy cows. J Dairy Sci 87, 2211-2221.

Gozho GN, T Mutsvangwa. 2008. Influence of carbohydrate source on ruminal fermentation characteristics, performance, and microbial protein synthesis in dairy cows. $J$ Dairy Sci 91, 2726-2735.

Hernandez-Mendo O, JD Leaver. 2004. Effect of replacing time available from grazing with time available for eating maize silage and soyabean meal on milk yield and feeding behavior in dairy cows. Grass Forage Sci 59, 318-330.

Horan B, P Dillon, P Faverdin, L Delaby, F Buckley, M Rath. 2005. The interaction of strain of Holstein-Friesian cows and pasture-based feed systems on milk yield, body weight, and body condition score. J Dairy Sci 88,12311243.

Kaneko JJ, JW Harvey, ML Bruss. 2008. Clinical biochemistry of domestic animals. Academic Press San Diego, USA.

Kennedy J, P Dillon, L Delaby, P Faverdin, G Stakelum, M Rath. 2003. Effect of genetic merit and concentrate supplementation on grass intake and milk production with Holstein Friesian dairy cows. J Dairy Sci 86, 610-621.

Kennedy E, M O’Donovan, FP O’Mara, JP Murphy, L Delaby. 2007. The effect of early-lactation feeding strategy on the lactation performance of spring-calving dairy cows. $J$ Dairy Sci 90, 3060-3070.

Kennedy E, M O'Donovan, L Delaby, FP O’Mara. 2008. Effect of herbage allowance and concentrate supplementation on dry matter intake, milk production and energy balance of early lactating dairy cows. Livest Sci 117, 275-286.

Kolver ES, LD Muller. 1998. Performance and nutrient intake of high producing Holstein cows consuming pasture or a total mixed ration. J Dairy Sci 81, 1403-1411.

Kuoppala K, S Yrjänen, S Jaakkola, R Kangasniemi, J Sariola, H Khalili. 2004. Effects of increasing concentrate energy supply on the performance of loose-housed dairy cows fed grass silage-based diets. Livest Produc Sci 85,15-26.

McEvoy M, E Kennedy, JP Murphy, TM Boland, L Delaby, M O'Donovan. 2008. The effect of herbage allowance and concentrate supplementation on milk production performance and dry matter intake of spring-calving dairy cows in early lactation. J Dairy Sci 91, 1258-1269.

Noro M, P Sepúlveda, F Cárdenas, RH Chihuailaf, F Wittwer. 2013. Rumenocentesis dorsomedial: un procedimiento seguro para la obtención de líquido ruminal en vacas lecheras a pastoreo. Arch Med Vet 45, 25-32.

Pacheco D, GC Waghorn. 2007. Dietary nitrogen-definitions, digestion, excretion and consequences of excess for grazing ruminants. Proceedings of the New Zealand Grassland Association 70, 107-116.

Pérez-Prieto L, JL Peyraud, R Delagarde. 2011. Substitution rate and milk yield response to corn silage supplementation of late-lactation dairy cows grazing low-mass pastures at 2 daily allowances in autumn. J Dairy Sci 94, 3592-3604.

Peyraud JL, EA Comeron, MH Wade, G Lemaire. 1996. The effect of daily herbage allowance, herbage mass and animal factors upon herbage intake by grazing dairy cows. Ann Zootech 45, 201-217. 
Peyraud JL, L Delaby. 2001. Ideal concentrate feeds for grazing dairy cows responses to supplementation in interaction with grazing management and grass quality. In: Garnsworthy PC, Wiseman J (eds). Recent Advances in Animal Nutrition. Nottingham University Press, Nottingham, UK.

Phillips CJC, JD Leaver. 1985. Supplementary feeding of forage to grazing dairy cows. 2 . Offering grass silage in early and late season. Grass Forage Sci 40, 193-199.

Phillips CJC. 1993. Cattle behaviour. Farming Press Books, Ipswich, UK

Poff AJ, O Balocchi, FI López. 2011. Sward and tiller growth dynamics of Lolium perenne L. as affected by defoliation frequency during autumn. Crop Pasture Sci 62, 346-354.

Pulido RG, JD Leaver. 2001. Quantifying the influence of sward height, concentrate level and initial milk yield on the milk production and grazing behaviour of continuously stocked dairy cows. Grass Forage Sci 56, 57-67.

Pulido RG, JD Leaver. 2003. Continuous and rotational grazing of dairy cows; the interactions of grazing system with level of milk yield, sward height and concentrate level. Grass Forage Sci 58, 265-275.

Pulido RG, R Muñoz, P Lemarie, F Wittwer, P Orellana, GC Waghorn. 2009. Impact of increasing grain frequency on production of dairy cows grazing pasture. Livest Sci 125 , 109-114.

Pulido R, R Muñoz, C Jara, O Balocchi, JP Smulders, F Wittwer, P Orellana, MA O' Donovan. 2010. The effect of pasture allowance and concentrate supplementation type on milk production performance and dry matter intake of autumn-calving dairy cows in early lactation. Livest Sci $132,119-125$.

Ruiz-Albarrán M, OA Balocchi, M Noro, F Wittwer, RG Pulido. 2012. Effect of increasing pasture allowance and grass silage on animal performance, grazing behaviour and rumen fermentation parameters of dairy cows in early lactation during autumn. Livest Sci 150, 407-413.

Russell JB, RJ Wallace. 1997. Energy-yielding and energy consuming reactions. Hobson PN, Stewart CS (eds). The Rumen Microbial Ecosystem. $2^{\text {nd }}$ ed. Blackie Academic and Professional, London, UK.
Sairanen A, H Khaliji, P Virkajarvi. 2006. Concentrate supplementation responses of the pasture-fed dairy cow. Livest Sci 104, 292-302.

SAS. 2004. SAS User's Guide: Statistics. SAS Inst. Inc. Cary, North Carolina, USA.

Soil Survery Satt. 1992. Keys to soil taxonomy. $5^{\text {th }}$ ed. Pocahontas Press Blackburg, Virginia, USA.

Sotelo J, M Noro, F Wittwer, JP Smulders, RG Pulido. 2012. Evaluation of the herbage allowance and type of concentrate on some ruminal parameters of grazing dairy cows during autumn. Arch Med Vet 44, 167-172.

Stockdale CR. 1999. The nutritive characteristics of herbage consumed by grazing dairy cows affect milk yield responses obtained from concentrate supplementation. Aust J Exp Agri 39, 379-387.

Stockdale CR. 2000. Levels of pasture substitution when concentrates are feed to grazing dairy cows in northern Victoria. Aust J Exp Agri 40, 913-921.

Tas BM, A Susenbeth. 2007. Urinary purine derivates excretion as an indicator of in vivo microbial $\mathrm{N}$ flow in cattle: $A$ review. Livest Sci 111, 181-192.

Tilley JMA, RA Terry. 1963. A two-stage technique for the in vitro digestion of forage crops. J Br Grassl Soc 18, 104-111.

Topps JH, RC Elliot. 1965. Relationship between concentrations of ruminal nucleic acids and excretion of purine derivatives by sheep. Nature 205, 498-499.

Valadares RF, GA Broderick, SC Valadares Filho, MK Clayton. 1999. Effect of replacing alfalfa silage with high moisture corn on ruminal protein synthesis estimated from excretion of total purine derivatives. J Dairy Sci 82, 2686-2696.

Van Soest PJ, JB Robertson, BA Lewis. 1991. Methods for dietary fiber, neutral detergent fiber and nonstarch polysaccharides in relation to animal nutrition. J Dairy Sci 74, 3583-3597.

Waghorn GC, JL Burke, ES Kolver. 2007. Principles of feeding value. In: Rattray PV, Brookes IM, Nicol AM (eds). Pasture and Supplements for Grazing Animals. New Zealand Society of Animal Production, Hamilton, New Zealand, Pp 35-59.

Wittwer F, P Gallardo, J Reyes, H Opitz. 1999. Bulk milk urea in grazing dairy herds. Vet Prev Med 38, 159-166. 